\title{
Aqueous Extracts of Plants on the Physiological and Sanitary Quality of Chenopodium Quinoa Seeds as an Alternative to Conventional Seed Treatment
}

\author{
Henrique Fernando Lidório (Corresponding Author), José Cardoso Sobrinho, Janine Farias \\ Menegaes, José Domingos Jacques Leão, Ubirajara Russi Nunes, Janete Denardi Munareto, \\ Geovana Facco Barbieri, Angelo Lorensi Leivas \\ Federal University of Santa Maria - UFSM, Brazil
}

Received: Nov. 17, 2019

Accepted: Dec. 20, 2019 Published: Jan. 3, 2020

doi:10.5296/jas.v8i2.15848

URL: https://doi.org/10.5296/jas.v8i2.15848

\begin{abstract}
This work evaluated the effect of aqueous plant extracts from chrysanthemum (Dendranthema grandiflora Tzvelev), cinnamon (Melia azedarach L.) and clove (Syzygium aromaticum L.) in the physiological and sanitary quality of germinating Chenopodium quinoa Willd (quinoa) seeds, as an alternative to seed treatment. The experiment was carried out under laboratory conditions in the year 2018. The experimental design was completely randomized in a $2 \times 10$ factorial scheme (two lots of quinoa seeds $\times$ ten doses of concentrated plant extracts), with four replicates each. The quinoa seeds were exposed to the plant extracts separately for ten minutes by submersion at the concentrations of $0,1,5$ and $10 \%$. The variables evaluated were germination, first germination count, field emergence, germination and emergence speed index, seedling length and sanity. The aqueous plant extracts of Dendranthema grandiflora Tzvelev, Melia azadarach L. and Syzygium aromaticum L. used in the quinoa seed treatment raised the emergence speed and the fungi control of these seeds within the variations and situations of each batch. The D. grandiflora extract, in all concentrations used, improved seed germination index, obtaining the highest rate of $70 \%$ in seeds treated with 5\% concentration compared to the control treatment, which obtained 59\%. M. azedarach ( $10 \%$ concentration) is the best treatment for emergence speed improvement, while $S$. aromaticum (10\% concentration) provides the highest control of pathogens: $28 \%$ in relation to the control treatment that obtained $75 \%$. These results highlighted the viability of the use of these species with low toxicity to man and the environment as treatment of quinoa seeds.
\end{abstract}

Keywords: quinoa, sanity of seeds, dendranthema grandiflora tzvelev, melia azedarach 1, syzygium aromaticum 1 


\section{Introduction}

The Chenopodium quinoa Willd (quinoa) is a pseudo cereal from the Chenopodiaceae family, native to the Andes mountains and introduced in Brazil during the 90s. Peru is the world leading grower of quinoa with around 50 thousand tons year ${ }^{-1}$, corresponding to $50.4 \%$ of the South American production (Faostat, 2014). In Brazil, however, low production levels have so far constrained the growing and trading of this pseudo cereal, demanding a considerable amount of imports in order to meet the national demand (Borges et al., 2010).

Its use as human food has grown due to its high nutritional value, low cholesterol levels and, especially, absence of gluten (Gewehr et al., 2012; Jellen et al., 2014; Strenske et al., 2015; Souza, 2016). Furthermore, quinoa seeds display fast germination in high-rainfall environments and no dormancy (Spehar and Santos, 2002), allowing its cultivation on commercial scale. Regarding production problems, quinoa seeds are particularly susceptible to pathogens attacks and the diseases resulted therein. Fungi of the genera Aspergillus, Alternaria and Fusarium are among the most relevant and prevalent ones, with high potential to affect the development of the plants and, consequently, the yield of quinoa seeds (Silva, 2009).

Ongoing advances in the use of chemical products (e.g. pesticides) for seed pathogens control have led to quick and significant improvements in the control of agricultural diseases, consequently increasing the overall sanitary quality of crop seeds. However, the excessive and incorrect use of these products ended up favoring the selection of pathogen strains resistant to these mechanisms (Martins et al., 2009), raising the demand for alternatives to conventional pesticides. In this context, certain substances obtained from plant extracts have been often used to control plant pathogens in seeds due to its high effectiveness and low toxicity to human health and natural environments (Venturoso et al., 2011; Medeiros et al., 2015).

Among plant species with natural insecticidal and fungicidal properties, the azedarachti of $M$. azedarach (Lovatto et al., 2012), the eugenol and beta-caryophyllene of S. aromaticum (Cardoso et al., 2007) and the pyrethrin of D. grandiflora (Gazola et al., 2009) stand out. These substances can be obtained from plants in a relatively simple way and in sufficient amount to be used in the control of fungi and insects, through extraction with aqueous or organic solvents, distillation or steam (Balandrin et al., 1985; Vivan, 2005). Several methods, however, are cited on literature for the extraction of these compounds, with the choice relying on economic viability among other factors (Franzen et al., 2018).

In this context, the aim of this work, which was to evaluate the effect of aqueous plant extracts from $D$. grandiflora, $M$. azedarach and $S$. aromaticum in the physiological and sanitary quality of quinoa seeds (C. quinoa) as an alternative to seed treatment with pesticides, has not been found in any studies. In relation to other species used as pathogen control in plants mentioned in the literature, the species chosen have in many studies been found to be highly effective and to have low toxicity to humans and the environment, besides the ease of finding them in the nature or at a relatively low cost, being easily available to agricultural producers. 


\section{Materials and Methods}

The experiment was carried out during 2018 in a completely randomized experimental design, with a $2 \times 10$ factorial scheme (two lots of quinoa seeds $\times$ ten doses of concentrated plant extracts), and four replicates each. The lots of quinoa seeds came from an experimental cultivation area at the Santa Maria Federal University (UFSM), in 2017. The seeds that formed Lots 1 and 2 (genotypes Q-1303 and Q-1331, respectively) were harvested, cleaned and stored for five months in a cold chamber $\left(15^{\circ} \mathrm{C}\right.$ and $\left.40 \% \mathrm{HR}\right)$, with initial moisture of $12.2 \%$.

\subsection{Plant Extracts}

The treatments with plant extracts were collected from $S$. aromaticum flower buds, $M$. azedarach leaves and D. grandiflora leaves, according to Mazaro et al. (2008) with adaptations. The leaves of each species were grounded, separately, in a processor with 100 $\mathrm{mL}$ of distilled water in the concentrations of $0 \%$ (experimental), $1 \%\left(1 \mathrm{~g} 100 \mathrm{~mL}^{-1}\right.$ distilled water), $5 \%$ (5 g $100 \mathrm{~mL}^{-1}$ distilled water) and $10 \%\left(10 \mathrm{~g} 100 \mathrm{~mL}^{-1}\right.$ distilled water). The liquid obtained in each extract passed by storage process, decanting for $24 \mathrm{~h}$ in closed locker without light and at room temperature. After the time elapsed, the filtration was held, separately, in Wathamann ${ }^{\circ} 1$ paper and each material were identified. After the filtration process and the identification of the aqueous plant extracts of each species, the quinoa seeds were treated by submersion for 10 minutes at concentrations of $0,1,5$ and $10 \%$ of each plant extract, and evaluated throughout germination process for physiological quality assessment.

The evaluated variables were the germination pattern test, first germination count, field emergence, germination and emergence speed index, seedling length (root and shoot) and sanity, according to the following methodologies:

\subsection{Germination Patter Test and First Germination Count}

Four replicates of 100 seeds were used, which were prepared in Gerbox ${ }^{\circledR}$ boxes with three sheets of filter paper moistened with distilled water, corresponding to 2.5 times their weight, and settled in a B.O.D. (Box Organism Development) germination chamber at $20^{\circ} \mathrm{C}$ for six days, with photoperiod of $16 \mathrm{~h}$. Vigor and germination assessments were done four and six days after sowing (DAS), and then the count of normal seedlings was carried out. Seedlings that presented more than $1.5 \mathrm{~cm}$ and above-ground part and root system well developed were considered normal. The results were expressed as percentage of normal seedlings, damaged abnormal seedlings, infected abnormal seedlings and total dead seeds (Brazil, 2009a). Additionally, daily evaluations were held in order to determine the germination speed index (GVI), according to the methodology proposed by Maguire (1962).

\subsection{Field Emergence and Germination Speed Index}

Four replicates of 50 seeds were used. Each replicate were sown in substrate, on $1 \mathrm{~m}$-rows spaced $0.2 \mathrm{~m}$ and $0.03 \mathrm{~m}$ deep. The emergence speed index was determined by daily evaluations according to the methodology proposed by Maguire (1962). The emergence evaluation was held at 14 days after sowing (DAS). 


\subsection{Seedling Length}

Four replicates of 50 seeds were used, each one were sown in Gerbox ${ }^{\circledR}$ and kept in the same germination conditions mentioned above. The length of the above-ground part and of the radicle was assessed for ten normal seedlings per replicate, at each day after sowing (DAS) (Nakagawa, 1999).

\subsection{Sanity Test on Filter Paper}

After submersion in each plant extract concentration, four replicates of 50 seeds each were incubated on paper substrate (Blotter Test), following the same methodology described above. Germination was inhibited by the freezing method for $24 \mathrm{~h}$. The seeds remained in the B.O.D for five days, at $20 \pm 2{ }^{\circ} \mathrm{C}$ and photoperiod of $12 \mathrm{~h}$. The percentage of infested seeds and the genera of infesting pathogens were assessed with the aid of a magnifying glass (microscope stereoscope) (Brazil, 2009b).

\subsection{Statistical Analysis}

The data expressed as percentages were transformed into $\sqrt{\mathrm{x} / 100}$ arc sine. The analyses of data variance and mean comparison through Tukey's test $(\mathrm{P}>0.05)$ were carried out in the statistical program R Core Team (2018).

\section{Results and Discussion}

\subsection{Germination}

In the initial test, the quinoa seeds presented 59\% of germination in lot 1 and $61 \%$ in lot 2 . Seed vigor (i.e. first germination count) was not significantly affected by the use of plant extracts, and germination did not differ between the tested lots. However, when considering the conditions of each lot, there was an increase in germination potential when the seeds were treated with $D$. grandiflora plant extract at different concentrations, highlighting the ones treated with a $5 \%$ concentration, where $8 \%$ of germination increase was obtained. Hüller and Schock (2011) point out that germination is one of the most used parameters to identify allopathic effects, since its determination is considered of simple evaluation.

Vigor and germination of abnormal seedlings (including damaged seedlings and the ones infested in the germination test) was not significantly affected by the extracts and concentrations evaluated (Table 1). Nonetheless, when comparing each specific lot, the use of plant extracts provided a significant decrease in the number of infected and damaged abnormal plants (Table 1). The lowest indices were obtained in the seeds of lot 1 , where the concentrations of $5 \%$ of S. aromaticum and $1 \%$ of M. azedarach resulted in $18 \%$ and $20 \%$ of damaged abnormal plants, respectively, when compared to the control treatment with $35 \%$ of damaged abnormal plants. 
Table 1. First germination count, germination, abnormal seedlings, total dead seeds, germination speed index, emergence, emergence speed index, root length and above-ground part length of two lots of quinoa seeds ( $C$. quinoa) treated with different plant extracts

\begin{tabular}{|c|c|c|c|c|c|c|}
\hline \multirow{2}{*}{ Extract $(\%)$} & \multicolumn{3}{|c|}{ First germination count $(\%)$} & \multicolumn{3}{|c|}{ Germination (\%) } \\
\hline & Lot 1 & Lot 2 & Mean & Lot 1 & Lot 2 & Mean \\
\hline Control & $53^{\mathrm{ns}}$ & 59 & $56 \mathrm{a}$ & $59^{\mathrm{ns}}$ & 61 & $60 \mathrm{a}$ \\
\hline D. grandiflora $1 \%$ & 55 & 57 & $56 a$ & 68 & 62 & $65 a$ \\
\hline D. grandiflora $5 \%$ & 64 & 58 & $61 \mathrm{a}$ & 70 & 60 & $65 a$ \\
\hline D. grandiflora $10 \%$ & 55 & 61 & $58 \mathrm{a}$ & 67 & 63 & $65 a$ \\
\hline M. azedarach $1 \%$ & 64 & 56 & $60 \mathrm{a}$ & 72 & 57 & $64 a$ \\
\hline M. azedarach 5\% & 56 & 57 & $57 \mathrm{a}$ & 58 & 59 & $58 \mathrm{a}$ \\
\hline M. azedarach $10 \%$ & 57 & 58 & $58 \mathrm{a}$ & 63 & 59 & $61 \mathrm{a}$ \\
\hline S. aromaticum $1 \%$ & 60 & 46 & $53 \mathrm{a}$ & 63 & 48 & $55 \mathrm{a}$ \\
\hline S. aromaticum $5 \%$ & 56 & 52 & $54 \mathrm{a}$ & 68 & 54 & $61 \mathrm{a}$ \\
\hline S. aromaticum $10 \%$ & 57 & 54 & $56 \mathrm{a}$ & 65 & 56 & $60 \mathrm{a}$ \\
\hline Average & $58 \mathrm{~A}$ & $56 \mathrm{~A}$ & & $65 \mathrm{~A}$ & $58 \mathrm{~B}$ & \\
\hline $\mathrm{CV}(\%)$ & & 6.68 & & & 6.75 & \\
\hline Dp: & & 3.81 & & & 4.15 & \\
\hline
\end{tabular}

Abnormal seedlings (\%)

Total dead seeds $(\%)$

\begin{tabular}{lcccccc}
\hline & Lot 1 & Lot 2 & Mean & Lot 1 & Lot 2 & Mean \\
\hline Control & 35Aa & $35 \mathrm{Aab}$ & 35 & $7^{\text {ns }}$ & 5 & $6 \mathrm{~b}$ \\
D. grandiflora $1 \%$ & $23 \mathrm{Babc}$ & $27 \mathrm{Ab}$ & 25 & 10 & 12 & $11 \mathrm{ab}$ \\
D. grandiflora $5 \%$ & $22 \mathrm{Bbc}$ & $28 \mathrm{Ab}$ & 25 & 9 & 12 & $11 \mathrm{ab}$
\end{tabular}


$\begin{array}{lllllll}\text { D. grandiflora } 10 \% & 26 \mathrm{Babc} & \text { 31 Aab } & 28 & 8 & 7 & 8 \mathrm{ab}\end{array}$

$\begin{array}{lllllll}\text { M. azedarach } 1 \% & 20 \mathrm{Bc} & 34 \mathrm{Aab} & 27 & 9 & 10 & 10 \mathrm{ab}\end{array}$

$\begin{array}{lllllll}\text { M. azedarach } 5 \% & 33 \mathrm{Aab} & 29 \mathrm{Ab} & 31 & 10 & 12 & 11 \mathrm{ab}\end{array}$

$\begin{array}{lllllll}\text { M. azedarach } 10 \% & 23 \mathrm{Babc} & 27 \mathrm{Ab} & 25 & 15 & 15 & 15 \mathrm{a}\end{array}$

$\begin{array}{lllllll}\text { S. } \text { aromaticum } 1 \% & 21 \mathrm{Bbc} & \text { 45Aa } & 33 & 17 & 8 & 13 \mathrm{a}\end{array}$

$\begin{array}{lllllll}\text { S. } \text { aromaticum } 5 \% & \text { 18Bc } & \text { 37Aab } & 27 & 10 & 9 & 10 \mathrm{ab}\end{array}$

$\begin{array}{lllllll}\text { S. } \text { aromaticum } 10 \% & \text { 26Babc } & \text { 31 Aab } & 28 & 10 & 14 & 12 \mathrm{a}\end{array}$

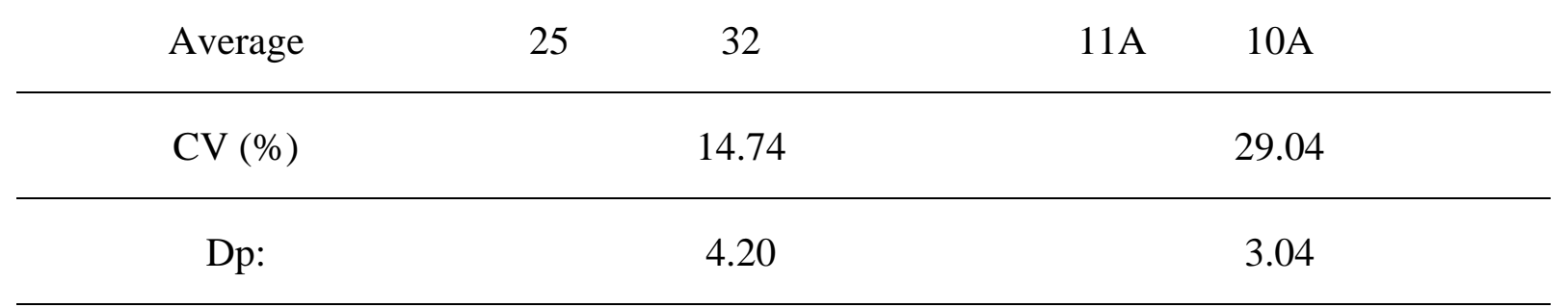

Germination speed index

Emergence (\%)

\begin{tabular}{lcccccc}
\hline & Lot 1 & Lot 2 & Mean & Lot 1 & Lot 2 & Mean \\
\hline Control & $63^{\text {ns }}$ & 82 & $72 \mathrm{a}$ & 57 & 54 & $55 \mathrm{~b}$ \\
D. grandiflora 1\% & 62 & 87 & $74 \mathrm{a}$ & 65 & 69 & $67 \mathrm{ab}$ \\
D. grandiflora 5\% & 63 & 81 & $72 \mathrm{a}$ & 65 & 60 & $62 \mathrm{ab}$ \\
D. grandiflora 10\% & 62 & 78 & $70 \mathrm{a}$ & 67 & 63 & $65 \mathrm{ab}$ \\
M. azedarach 1\% & 65 & 79 & $72 \mathrm{a}$ & 68 & 64 & $66 \mathrm{ab}$ \\
M. azedarach 5\% & 70 & 78 & $74 \mathrm{a}$ & 73 & 69 & $71 \mathrm{a}$ \\
M. azedarach 10\% & 63 & 78 & $71 \mathrm{a}$ & 67 & 67 & $67 \mathrm{ab}$ \\
S. aromaticum 1\% & 62 & 88 & $75 \mathrm{a}$ & 66 & 62 & $64 \mathrm{ab}$ \\
S. aromaticum 5\% & 61 & 76 & $68 \mathrm{a}$ & 58 & 69 & $63 \mathrm{ab}$
\end{tabular}


S. aromaticum $10 \%$

59

78

$68 \mathrm{a}$

68

63

$65 \mathrm{ab}$

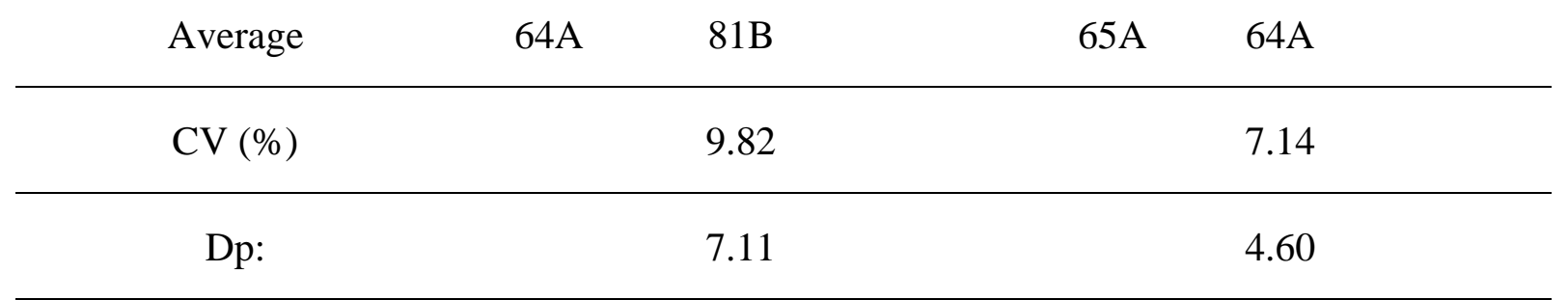

Emergence speed index

Root length (mm)

\begin{tabular}{|c|c|c|c|c|c|c|}
\hline & Lot 1 & Lot 2 & Mean & Lot 1 & Lot 2 & Mean \\
\hline Control & $37 \mathrm{Bc}^{*}$ & 40Acd & 38 & 1.2 & 2.2 & $1.7 \mathrm{a}$ \\
\hline D. grandiflora $1 \%$ & 48Aab & 47Aabc & 48 & 0.7 & 1.5 & $1.1 \mathrm{~b}$ \\
\hline D. grandiflora $5 \%$ & $55 \mathrm{Aa}$ & 44Babcd & 50 & 0.6 & 1.5 & $1.0 \mathrm{~b}$ \\
\hline D. grandiflora $10 \%$ & $43 \mathrm{Abc}$ & 42Abcd & 43 & 0.5 & 1.2 & $0.8 \mathrm{~b}$ \\
\hline M. azedarach $1 \%$ & $50 \mathrm{Aab}$ & $52 \mathrm{Aa}$ & 51 & 0.6 & 1.5 & $1.0 \mathrm{~b}$ \\
\hline M. azedarach 5\% & $51 \mathrm{Aab}$ & 45Babc & 48 & 0.8 & 1.4 & $1.1 \mathrm{~b}$ \\
\hline M. azedarach $10 \%$ & 48Bab & $50 \mathrm{Aab}$ & 49 & 0.5 & 1.8 & $1.1 \mathrm{~b}$ \\
\hline S. aromaticum $1 \%$ & $45 \mathrm{Abc}$ & $35 \mathrm{Bd}$ & 40 & 0.6 & 1.9 & $1.2 \mathrm{ab}$ \\
\hline S. aromaticum $5 \%$ & $35 \mathrm{Bc}$ & 42Abcd & 39 & 0.7 & 1.8 & $1.2 \mathrm{ab}$ \\
\hline S. aromaticum $10 \%$ & 47Aab & 39Bcd & 43 & 0.6 & 1.6 & $1.1 \mathrm{~b}$ \\
\hline Average & 46 & 44 & & $0.680 \mathrm{~A}$ & 1.640B & \\
\hline $\mathrm{CV}(\%)$ & & 14.25 & & & 25.39 & \\
\hline Dp: & & 6.41 & & & 0.29 & \\
\hline
\end{tabular}

Above-ground part length (mm)

Lot 1 Lot 2 Mean




\begin{tabular}{|c|c|c|c|}
\hline Control & $1.8 \mathrm{Ba}$ & $2.5 \mathrm{Aab}$ & 2.1 \\
\hline D. grandiflora $1 \%$ & $1.9 \mathrm{Ba}$ & 2.1Acde & 2 \\
\hline D. grandiflora $5 \%$ & 1.7Babc & 2.3Abcd & 2 \\
\hline D. grandiflora $10 \%$ & $1.8 \mathrm{Bab}$ & $2.6 \mathrm{Aa}$ & 2.2 \\
\hline M. azedarach $1 \%$ & $1.4 \mathrm{Bc}$ & $2.5 \mathrm{Aab}$ & 1.9 \\
\hline M. azedarach $5 \%$ & 1.6Aabc & 1.9Aef & 1,7 \\
\hline M. azedarach $10 \%$ & $1.5 \mathrm{Bbc}$ & 2.5Aabc & 2 \\
\hline S. aromaticum $1 \%$ & 1.6Babc & 2.4Aabc & 2 \\
\hline S. aromaticum $5 \%$ & 1.7Babc & 2.1Adef & 1.9 \\
\hline S. aromaticum $10 \%$ & 1.8Aabc & $1.8 \mathrm{Af}$ & 1.8 \\
\hline Average & 1.680 & 2.270 & \\
\hline $\mathrm{CV}(\%)$ & & 12.31 & \\
\hline Dp: & & 0.24 & \\
\hline
\end{tabular}

Note. *Significant interaction and ${ }^{\mathrm{ns}}$ non-significant interaction of factors; the average not followed by the same letter, uppercase in the row and lower case in the column, differ by the Tukey test. CV: coefficient of variation.

The length of the root and above-ground parts of the seedlings were negatively affected by the plant extracts at $10 \%$ concentration (Table 1). Iganci et al. (2006) described that compounds with allopathic effects can inhibit germination and growth, negatively participating in cell division, in the activation of enzymes and absorbance of membranes. Although toxicity levels in the plant extracts were not detected in the tests, the reductions observed in root length and above-ground part length can be attributed to the conclusions of Rabêlo (2010) who observed that S. aromaticum essential oil is highly toxic to larvae of Artemiasalina, due to the presence of eugenol.

Emergence speed index (ESI) in the two lots of seeds was significantly improved by the plant extracts, at all concentrations. For the seeds in lot 1, the most significant value was observed in the seeds treated with D. grandiflora (5\%), obtaining the index of 55.55 in relation to the control, which presented 37.1. 
Germination speed index (GSI) did not show a significant difference in both seed lots tested. when considering the interactions within each lot, the lowest index was verified in the seeds of lot 1, which presented the value of 59 when treated with S. aromaticum (10\%), in relation to the control, which presented 62.95 (Table 1). Similar results were found by Gonçalves et al. (2003), who concluded that seeds treated with S. aromaticum (10\%) and subsequently stored in metal packages showed reduction of GSI.

\subsection{Plant Pathogen Control}

All treatments presented lower fungi incidence than the control treatment in both tested lots, but inferior results were obtained in lot 1 when compared to lot 2. Phytopathogens infested 75 and $25 \%$ of the quinoa seeds from lots 1 and 2, respectively, with predominance of the genera Aspergillus spp., Fusarium spp., Penicillium spp., and Sclerotinia spp. (Table 2).

The statistical analysis for sanitary test differed significantly between the two lots. Except for the treatments with $M$. azedarach extracts $(1 \%, 5 \%$ and $10 \%)$, quinoa seeds from lot 1 obtained a favorable sanitary quality index in relation to the control plot, which presented $75 \%$ of phytopathogen incidence. When the seeds were treated with $S$. aromaticum $(10 \%)$ and D. grandiflora (10\%), sanitary indexes of $28 \%$ and $33 \%$ were obtained, respectively. Medeiros et al. (2015) concluded that efficient fungi control contributes to the reduction of microflora in the surface of the seeds, allowing the increase of germination percentage under field and laboratory conditions.

Out of all pathogen genera identified, the genus Aspergillus spp. was the one that presented the highest incidence in the seeds of lots 1 and 2, with $45 \%$ and $61 \%$ respectively, indicating that the plant extracts tested do not inhibit the growth of Aspergillus spp. No significant results were found regarding growth inhibition of Sclerotinia spp. (Table 2) in the comparison between the two lots of seeds.

Table 2. Incidence of phytopathogens from the genera Aspergillus, Fusarium, Penicillum and Sclerotinia on the two lots of quinoa seeds (C. quinoa) treated with different plant extracts

\begin{tabular}{ccccccc}
\hline \multirow{2}{*}{ Extract $(\%)$} & \multicolumn{3}{c}{ Infested seeds (\%) } & \multicolumn{2}{c}{ Aspergillus spp. (\%) } \\
\cline { 2 - 7 } & Lot 1 & Lot 2 & Mean & Lot 1 & Lot 2 & Mean \\
\hline Control & $75 \mathrm{Aa}^{*}$ & $25 \mathrm{Bcd}$ & 50 & $16 \mathrm{Bc}^{*}$ & $62 \mathrm{Aa}$ & 39 \\
D. grandiflora $1 \%$ & $73 \mathrm{Aab}$ & $16 \mathrm{Bd}$ & 45 & $33 \mathrm{Bb}$ & $74 \mathrm{Aa}$ & 53 \\
D. grandiflora $5 \%$ & $69 \mathrm{Aab}$ & $34 \mathrm{Bbc}$ & 52 & $43 \mathrm{Bab}$ & $67 \mathrm{Aa}$ & 55 \\
D. grandiflora $10 \%$ & $33 \mathrm{Ade}$ & $31 \mathrm{Abc}$ & 32 & $40 \mathrm{Bab}$ & $63 \mathrm{Aa}$ & 51 \\
M. azedarach $1 \%$ & $44 \mathrm{Acd}$ & $42 \mathrm{Aab}$ & 43 & $47 \mathrm{Aab}$ & $49 \mathrm{Aa}$ & 48 \\
M. azedarach $5 \%$ & $74 \mathrm{Aa}$ & $33 \mathrm{Bbc}$ & 54 & $51 \mathrm{Aab}$ & $52 \mathrm{Aa}$ & 51 \\
M. azedarach $10 \%$ & $74 \mathrm{Aa}$ & $28 \mathrm{Bbc}$ & 51 & $55 \mathrm{Bab}$ & $60 \mathrm{Aa}$ & 57 \\
S. aromaticum $1 \%$ & $68 \mathrm{Aab}$ & $56 \mathrm{Ba}$ & 62 & $63 \mathrm{Ba}$ & $68 \mathrm{Aa}$ & 65
\end{tabular}


S. aromaticum 5\%

S. aromaticum $10 \%$

$53 \mathrm{Abc} \quad 25 \mathrm{Bcd}$

39

25
66Aa 58Ba

62

$36 \mathrm{Bb} \quad 60 \mathrm{Aa}$

61

23.37

23.37

12.37

\begin{tabular}{|c|c|c|c|c|c|c|}
\hline & \multicolumn{3}{|c|}{ Fusarium spp. (\%) } & \multicolumn{3}{|c|}{ Penicillum spp. (\%) } \\
\hline & Lot 1 & Lot 2 & Mean & Lot 1 & Lot 2 & Mean \\
\hline Control & $43^{\mathrm{ns}}$ & 35 & $39 a$ & $32 \mathrm{Aa}^{*}$ & $2 \mathrm{Ba}$ & 17 \\
\hline D. grandiflora $1 \%$ & 39 & 16 & $27 \mathrm{a}$ & 18Aabc & $\mathrm{OBa}$ & 9 \\
\hline D. grandiflora $5 \%$ & 26 & 21 & $23 \mathrm{a}$ & $10 \mathrm{Abc}$ & $4 \mathrm{Ba}$ & 7 \\
\hline D. grandiflora $10 \%$ & 32 & 28 & $30 \mathrm{a}$ & $7 \mathrm{Ac}$ & $4 \mathrm{Ba}$ & 5 \\
\hline M. azedarach $1 \%$ & 29 & 25 & $27 \mathrm{a}$ & 17Aabc & $6 \mathrm{Ba}$ & 11 \\
\hline M. azedarach $5 \%$ & 27 & 35 & $31 \mathrm{a}$ & $20 \mathrm{Aab}$ & $2 \mathrm{Ba}$ & 11 \\
\hline M. azedarach $10 \%$ & 22 & 25 & $23 \mathrm{a}$ & $18 \mathrm{Aabc}$ & $1 \mathrm{Ba}$ & 9 \\
\hline S. aromaticum $1 \%$ & 28 & 16 & $22 \mathrm{a}$ & $8 \mathrm{Abc}$ & $6 \mathrm{Ba}$ & 7 \\
\hline S. aromaticum $5 \%$ & 18 & 27 & $22 \mathrm{a}$ & $9 \mathrm{Abc}$ & $2 \mathrm{Ba}$ & 5 \\
\hline S. aromaticum $10 \%$ & 47 & 22 & $34 \mathrm{a}$ & $8 \mathrm{Abc}$ & $4 \mathrm{Ba}$ & 6 \\
\hline Average & $31 \mathrm{~A}$ & $25 \mathrm{~B}$ & & 14 & 3 & \\
\hline $\mathrm{CV}(\%)$ & & 28.37 & & & 68.90 & \\
\hline Dp: & & 7.94 & & & 5.86 & \\
\hline
\end{tabular}

\begin{tabular}{|c|c|c|c|}
\hline & \multicolumn{3}{|c|}{ Sclerotinia spp. (\%) } \\
\hline & Lot 1 & Lot 2 & Mean \\
\hline Control & $9 \mathrm{Aab}^{*}$ & $2 \mathrm{Bb}$ & 5 \\
\hline D. grandiflora $1 \%$ & 10Aab & $11 \mathrm{Aab}$ & 10 \\
\hline D. grandiflora $5 \%$ & $21 \mathrm{Aa}$ & $8 \mathrm{Bab}$ & 14 \\
\hline D. grandiflora $10 \%$ & $21 \mathrm{Aa}$ & $5 \mathrm{Bab}$ & 13 \\
\hline M. azedarach $1 \%$ & $7 \mathrm{Bab}$ & 19Aa & 13 \\
\hline M. azedarach $5 \%$ & $2 \mathrm{Bb}$ & $10 \mathrm{Aab}$ & 6 \\
\hline M. azedarach $10 \%$ & $4 \mathrm{Bb}$ & $14 \mathrm{Aab}$ & 9 \\
\hline S. aromaticum $1 \%$ & $1 \mathrm{Bb}$ & $10 \mathrm{Aab}$ & 5 \\
\hline S. aromaticum $5 \%$ & $7 \mathrm{Bab}$ & 13Aaba & 10 \\
\hline
\end{tabular}


S. aromaticum $10 \%$

Average

$\mathrm{CV}(\%)$

Dp:
9Bab

14Aab

10

\begin{tabular}{cc}
\hline $\mathrm{CV}(\%)$ & 69.29 \\
\hline $\mathrm{Dp}:$ & 6.58 \\
\hline
\end{tabular}

11

Note. *Significant interaction and ${ }^{\mathrm{ns}}$ non-significant interaction of factors; averages followed by the same uppercase letter in the row and lowercase in the columndo not differ by Tukey's test $(\mathrm{P}>0.05)$. $\mathrm{CV}$ : coefficient of variation.

The use of plant extracts at certain concentrations reduced infestation by Fusarium spp. Quinoa seeds from lot 2 treated with D. grandiflora (1\%) and S. aromaticum (1\%) presented incidence of $16 \%$ in both tests, against $35 \%$ of fungi incidence in the control plot. These results attest the benefits of seed treatment with plant extracts, providing improvement in the sanitary quality of the seeds and, consequently, in their physiological development.

No significant control of Penicillium spp. was observed in the quinoa seeds from lot 2. Yet, Seeds from lot 1 showed significant control, with fungi incidences of 8,9 and $8 \%$ when treated with plant extracts of S. aromaticum at $1 \%, 5 \%$ and $10 \%$ concentration, respectively, against $32 \%$ of incidence in the control plot. Amaral et al. (2005) concluded that the use of $S$. aromaticum provides significant control of seed phytopathogens at concentrations of $0.5 \%$ to $0.1 \%$. Overall, the sanitary tests revealed $75 \%$ and $25 \%$ of phytopathogen incidence in the quinoa seeds from lots 1 and 2, respectively. The use of aqueous plant extracts as seed treatment, at certain concentrations, provides a significant reduction in the infestation by fungi, improving the development of quinoa seeds.

The two lots differed statistically from each other, and it is worth highlighting that the quinoa seeds from lot 1 displayed less pathogen incidence than the control plot (75\%) for all plant extracts, except $M$. azedarach. Seeds treated with S. aromaticum (10\%) and D. grandiflora (10\%) presented sanitary indexes of $28 \%$ and $33 \%$, respectively. Accordingly, Medeiros, et al. (2015) states that efficient fungi control contributes to the reduction of microflora in the surface of the seeds, improving germination under field and laboratory conditions.

\section{Conclusion}

The aqueous plant extracts of clove (Syzygium aromaticum L.), cinnamon (Melia azadarach L.) and chrysanthemum (Dendranthema grandiflora Tzvelev) used in the quinoa seed treatment raised the emergence speed and the fungi control of these seeds within the variations and situations of each batch. The D. grandiflora extract, in all concentrations used, improved seed germination index, obtaining the highest rate of $70 \%$ in seeds treated with 5\% concentration compared to the control treatment, which obtained $59 \%$. M. azedarach $(10 \%$ concentration) is the best treatment for emergence speed improvement, while S. aromaticum (10\% concentration) provides the highest control of pathogens: $28 \%$ in relation to the control treatment that obtained $75 \%$. These results highlighted the viability of the use of these species with low toxicity to man and the environment as treatment of quinoa seeds. 


\section{References}

Amaral, M. F. Z. J. (2005). Avaliação da atividade antifúngica de extratos de plantas sobre o crescimento de fitopatógenos. Revista Eletrônica de Farmácia, 2(2), 5-8.

Balandrin, M. F., Klocke, J. A., Wurtele, E. S., \& Bollinge, W. H. (1985). Natural Plant Chemical: Sources of Industrial and Medicinal Materials. Science, 228, 1154-1160. https://doi.org/10.1126/science.3890182

Borges, J. T., Bonomo, R. C., Paula, C. D., Oliveira, L. C., Cesário, \& M. C. (2010). Características Físico-Químicas, Nutricionais e Formas de Consumo da Quinoa (Chenopodium quinoa Willd.). Temas Agrários, 15(1), 9-23.

https://doi.org/10.21897/rta.v15i1.815

Brazil. (2009a). Ministério da Agricultura, Pecuária e Abastecimento. Regras para Análise de Sementes. Brasília: MAPA, 395p.

Brazil. (2009b). Ministério da Agricultura, Pecuária e Abastecimento. Manual de Análise Sanitária de Sementes. Brasília: MAPA, 200p.

Cardoso, M. G., Santos, L. G. M., Cardoso, M. G., Lima, R. K., Souza, P. E., \& Andrade, M. A. (2007). Avaliação do potencial fungitóxico do óleo essencial de Syzygium aromaticum (L.) Merr \& Perry (cravo-da-índia). Tecno-Lógica, 11(1), 11-14.

http://dx.doi.org/10.17058/tecnolog.v11i1.154

R Core Team. (2018). R: A language and environment for statistical computing. $R$ Foundation for Statistical Computing. Vienna, Austria.

FAOSTAT. FAO-Statistics Division (2014). Retrieved from http://faostat.fao.org/site/567/DesktopDefault.aspx?PageID=567\#ancor

Franzen, F. L., Fries, L. L., Oliveira, M. S. R., Lidório, H. F., Menegaes, J. F., \& Lopes, S. J. (2018). Teor e rendimento de extratos de flores obtidos por diferentes métodos e períodos de extração. Acta Iguazu, 7(1), 9-21.

Gazola, D., Bellon, P. P., Rheinheimer, A. R., Miranda, A. M., Scherer, W. A., Pietrowski, V., \& Alves, L. F. A. (2009). Efeito do Extrato de Crisântemo sobre o Percevejo de Renda da Mandioca Vatiga manihotae (Hemiptera: Tingidae). Revista Brasileira de Agroecologia, 4(2).

Gewehr, M. F., Danelli, D., Melo, L. M. D., Flôres, S. H., \& Jong, E. V. D. (2012). Análises químicas em flocos de quinoa\&58; caracterização para a utilização em produtos alimentícios. Brazilian Journal of Food Technology, 15(4), 280-287.

https://doi.org/10.1590/S1981-67232012005000023

Gonçalves, E. P., Araújo, E., Alves, E. U., \& Costa, N. P. (2003). Tratamento químico e natural sobre a qualidade fisiológica e sanitária em sementes de feijão (Phaseolus vulgaris L.) armazenadas. Revista Biociências, 9(1).

Hüller, A., \& Schock, A. A. (2011). Avaliação do potencial alelopático de três espécies de Eugenia L. (Myrtaceae) sobre o processo germinativo de Lactuca sativa L. Revista de 
Ciências Ambientais, 5(1), 25-37.

Iganci, J. R. V., Bobrowski, V. L., Heiden, G., Stein, V. C., \& Rocha, B. H. G. (2006). Efeito do extrato aquoso de diferentes espécies de boldo sobre a germinação e índice mitótico de Allium cepa L. Arq Inst Biol, 73(1), 79-82.

Jellen, E. N., Maughan, P. J., Fuentes, F., \& Kolano, B. A. (2014). Botánica, Domesticación y Circulación de Recursos Genétcos. In: BAZILE D., Bertero, D., Nieto, C. (Eds) Estado del arte de La quinua en el mundo en 2013: FAO: Santiago, Chile: CIRAD: Montpellier, Francia, 2014, 11-35.

Lovatto, P. B., Martinez, E. A., Mauch, C. R., \& Schiedeck, G. (2012). A utilização da espécie Melia azedarach L. (Meliaceae) como alternativa à produção de insumos ecológicos na região sul do Brazil. Revista Brasileira de Agroecologia, 7(2), 137-149.

Maguire, J. D. (1962). Speed of germination aid in selection and evaluation for seedling emergence and vigor. Crop Science, 2(2), 176-177.

https://doi.org/10.2135/cropsci1962.0011183X000200020033x

Martins, M. T. C. S., Nascimento, L. C., Araujo, E. R., Rêgo, E. R., Bruno, R. L. A., \& Felix, L. P. (2009). Atividade antifúngica de extrato de melão-de-são-caetano em sementes de maniçoba. Horticultura Brasileira, 27(3), 1246-1253.

Mazaro, S. M., Citadin, I., Gouvêa, A., Luckmann, D., \& Guimarães, S. S. (2008). Indução de fitoalexinas em cotilédones de soja em resposta a derivados de folhas de pitangueira. Ciência Rural, 38(7), 1824-1829. https://doi.org/10.1590/S0103-84782008000700004

Medeiros, J. G. F., Neto, A. C. A., Silva, E. C., Huang, M. N., \& Nascimento, L. C. (2015). Qualidade sanitária de sementes de Caesalpinia ferrea: incidência de fungos, controle e efeitos na qualidade fisiológica com o uso de extratos vegetais. Floresta, 45(1), 163-174.

https://doi.org/10.5380/rf.v45i1.34074

Nakagawa, J. (1999). Testes de vigor baseados na avaliação das plântulas. In: Krzyzanoswki, F.C., Vieira, R.D., França Neto, J.B. Vigor de sementes: conceitos e testes. Londrina: ABRATES.

Rabêlo, W. F. (2010). Caracterização química, toxicidade e avaliação da atividade antibacteriana do óleo essencial do cravo da índia (Syzygium aromaticum). Master Thesis, Universidade Federal do Maranhão, São Luiz. Retrieve from https://ppgquim.ufma.br/uploads/files/Waleria\%20Ferreira\%20Rabelo.pdf.

Silva, A. P. S. (2009). Ocorrência de fungos em sementes de cinco linhagens Brasileiras de quinoa. Campo Digital, Campo Mourão, 4(1), 137-141.

Souza, J. E. A. (2016). Germinação de sementes de quinoa (Chenopodium quinoa Willd). Trabalho de conclusão de curso. Universidade de Brasília. Brasília, Distrito Federal.

Spehar, C. R., \& Santos, R. L. B. (2002). Quinoa (Chenopodium quinoa Willd) BRS Piabiru: Alternativa para diversificar os sistemas de produção de grãos. Pesquisa Agropecuária 


\section{Macrothink}

Journal of Agricultural Studies

ISSN 2166-0379 2020, Vol. 8, No. 2

Brasileira, Brasília, Distrito Federal, 37(6), 889-893.

https://doi.org/10.1590/S0100-204X2002000600020

Strenskel, A., Vasconcelos, E. S., Herzog, N. F. M., \& Malavasi, M. M. (2015). Germinação de sementes de quinoa com diferentes períodos de armazenamento. Scientia Agraria Paranaensis, 14, 286-290. https://doi.org/10.18188/1983-1471/sap.v14nsupp286-290

Venturoso, L. R., Bacchi, L. M. A., \& Gavassoni, W. L. (2011). Atividade antifúngica de extratos vegetais sobre o desenvolvimento de fitopatógenos. Summa Phytopathologica, 37(1), 18-23. https://doi.org/10.1590/S0100-54052011000100003

Vivan, M. P. (2005). Uso do cinamomo (Melia azedarach) como alternativa aos agroquímicos no controle do carrapato bovino (Boophilus microplus). Master Thesis). Universidade Federal de Santa Catarina. Florianópolis. Retrieved from

http://repositorio.ufsc.br/handle/123456789/101991

\section{Copyright Disclaimer}

Copyright for this article is retained by the author(s), with first publication rights granted to the journal.

This is an open-access article distributed under the terms and conditions of the Creative Commons Attribution license (http://creativecommons.org/licenses/by/4.0/). 